\title{
UJI FITOKIMIA DAN AKTIVITAS ANTIOKSIDAN EKSTRAK BUAH DAN KULIT PISANG JARUM (Musa acuminata var. Jarum (AA Group))
}

\author{
Fensia Analda Souhoka ${ }^{1}$, Yeanchon H. Dulanlebit ${ }^{2}$, dan Ester M. C. Tomasoa ${ }^{1}$ \\ ${ }^{1}$ Departement of Chemistry-FMIPA, Pattimura University Ambon \\ ${ }^{2}$ Departement of Chemistry-FKIP, Pattimura University Ambon
}

Diterima 15 Oktober 2018/Disetujui 01 Desember 2018

\begin{abstract}
This study aimed to determine phytochemical tests and antioxidant activity of fruit and peel extract of pisang jarum. Sample was extracted with $80 \%$ of ethanol, methanol, and acetone using reflux method. The result showed that pisang jarum extract contains phenols, flavonoids, and terpenoids, whereas peel extract contains phenols, flavonoids, terpenoids, alkaloids, and saponins. The total phenol content (TPC) of pisang jarum is $0.0250-0.0316 \mathrm{mg} \mathrm{PE} / \mathrm{g}$ extract and peel is $0,1756-0,2679 \mathrm{mg} \mathrm{PE} / \mathrm{g}$ extract. The total flavonoid content (TFC) of pisang jarum is $0.8412-1.4466 \mathrm{mg}$ QE/g extract and peel is $3.2128-5.1073 \mathrm{mg} \mathrm{QE} / \mathrm{g}$ extract. The antioxidant activity of extract were analyze by DPPH free radical scavenging activity. The antioxidant activities $\left(\mathrm{IC}_{50}\right)$ of pisang jarum is $1092.92-3871.24$ ppm and peel is $310.08-558.07 \mathrm{ppm}$, so it is classified as a weak antioxidant.
\end{abstract}

Keywords: antioxidant activity, ethanol-methanol-acetone extract, phytochemical test, pisang jarum

\section{PENDAHULUAN}

Antioksidan merupakan senyawa yang mendonorkan elektronnya untuk menghentikan reaksi berantai radikal bebas yang dapat merusak tubuh. Secara alami, senyawa antioksidan banyak terdapat dalam buah dan sayur. Pisang merupakan buah yang paling banyak dikonsumsi, baik secara langsung maupun melalui hasil olahan.

Gizi yang terkandung dalam buah pisang adalah kalium, magnesium, karbohidrat, lemak, fosfor, kalsium, vitamin $\mathrm{C}$, serat, protein, besi, vitamin A, vitamin $\mathrm{K}$, vitamin $\mathrm{E}$, tiamin, riboflavin, dan niasin (Nagarajaiah dan Prakash (2011); UNSCT (2007); USDA (2009)). Buah pisang mengandung senyawa antioksidan, yaitu flavonoid, polifenol, fenolik, $\beta$-karoten, dan tanin. Semakin banyak mengkonsumsi buah pisang, maka semakin besar pula senyawa antioksidan yang dapat diperoleh tubuh (Nagarajaiah dan Prakash (2011); Alhabsyi dkk. (2014); Saputro dan Sudarsono (2014); Kumar dkk. (2014)).

Salah satu jenis pisang yang khas dan sering dikonsumsi oleh masyarakat Maluku, yaitu pisang jarum (Musa acuminate var. Jarum (AA group)). Pisang jarum tak berbiji, berbau harum, manis, dan memiliki bentuk buah melengkung dengan ujung sedikit meruncing. Umumnya limbah kulit pisang hanya dimanfaatkan sebagai kompos dan pakan ternak (Satuhu dan Ahmad, 2005). Namun kini, kulit pisang telah diolah menjadi keripik, tepung (Nuramanah dkk., 2012), senyawa tabir surya, dan senyawa antioksidan (Alhabsyi dkk., 2014).

Jumroon dan Pannipa (2012) telah menguji aktivitas antioksidan buah pisang (AA Group) pada tiga kondisi (mentah, masak, dan lewat masak). Nilai TPC dan aktivitas antioksidan tertinggi diperoleh pada pisang masak dan lewat masak, sedangkan nilai TFC tertinggi pada pisang mentah. Pemanfaatan buah dan limbah kulit pisang jarum sebagai antioksidan belum dilaporkan. Oleh karena 
itu, dalam penelitian ini dilakukan uji fitokimia dan aktivitas antioksidan buah dan kulit pisang jarum terhadap DPPH (2,2-diphenyl-1-picrylhydrazyl) menggunakan spektrofotometri UV-Vis.

Senyawa antioksidan akan bereaksi dengan radikal bebas DPPH dengan cara mendonorkan atom hidrogen. Elektron radikal bebas DPPH menunjukkan serapan yang kuat pada $\lambda 517 \mathrm{~nm}$ dengan warna ungu gelap. Penangkapan radikal bebas membuat elektron menjadi berpasangan, sehingga menyebabkan hilangannya warna yang sebanding dengan jumlah elektron yang diambil (Prakash, 2001).

Dari hasil analisis akan dihitung nilai $\mathrm{IC}_{50}$ (inhibition concetration), yaitu konsentrasi larutan sampel yang dapat mereduksi DPPH sebesar $50 \%$. Suatu senyawa dikatakan memiliki aktivitas antioksidan sangat kuat jika nilai $\mathrm{IC}_{50}<50 \mathrm{ppm}$, kuat 50-100 ppm, sedang 100-250 ppm, dan lemah >250 ppm (Jun dkk., 2003).

Penelitian ini dilakukan dalam beberapa tahap, yaitu ekstraksi buah dan kulit pisang jarum dengan metode refluks menggunakan tiga pelarut, yaitu metanol, etanol, dan aseton masing-masing $80 \%$. Selanjutnya uji fitokimia terhadap masing-masing ekstrak meliputi uji fenolik, flavonoid, steroid, terpenoid, alkaloid, saponin, TPC, dan TFC, serta penentuan aktivitas antioksidan menggunakan metode DPPH.

\section{METODE PENELITIAN}

\section{Alat}

Alat yang digunakan, yaitu seperangkat alat gelas (Pyrex), seperangkat alat refluks (Pyrex) blender (Maspion), oven listrik (Shel Lab), neraca analitik (Ohauss), evaporator (Rotavapor R-215 Buchii), dan spektrofotometer UV-Vis (PD 303S).

\section{Bahan}

Bahan dasar yang digunakan, yaitu buah dan kulit pisang jarum. Bahan kimia dengan kualitas pro analisis dari Merck, yaitu metanol, etanol, aseton, $\mathrm{FeCl}_{3}$, serbuk $\mathrm{Mg}$, asam klorida, asam asetat anhidrat, asam sulfat, pereaksi Dragendroff, reagen Folin-Ciocalteu, natrium karbonat, $\mathrm{AlCl}_{3}, \mathrm{DPPH}$, dan kuersitin. Kertas saring dan akuades.

\section{Prosedur Kerja}

\subsection{Persiapan sampel}

Pisang jarum dicuci dan dikupas kulitnya. Buah pisang dihaluskan dengan blender hingga menjadi bubur. Kulit pisang diiris dengan ketebalan $\pm 2 \mathrm{~mm}$, kemudian dikeringkan dalam oven sampai beratnya konstan. Kulit pisang kering diblender, selanjutnya diayak sampai menjadi serbuk, kemudian disimpan dalam stoples kedap udara (Nagarajaiah dan Prakash (2011) dan Fatemeh dkk. (2012)).

\subsection{Ekstraksi}

Sampel bubur pisang dan serbuk kulit pisang jarum diekstrak dengan variasi jenis pelarut, yaitu metanol $80 \%$, etanol $80 \%$, dan aseton $80 \%$ menggunakan metode refluks.

Setiap $25 \mathrm{~g}$ sampel dimasukkan ke dalam labu destilat, ditambahkan masing-masing $150 \mathrm{~mL}$ pelarut hingga sampel terendam, kemudian campuran direfluks selama 2 jam. Hasil refluks disaring, selanjutnya filtrat diuapkan menggunakan evaporator. Setiap ekstrak diuji fitokimia dan aktivitas antioksidan menggunakan metode DPPH. 


\subsection{Uji Fitokimia}

Uji fitokimia dilakukan menggunakan masing-masing 0,01 g ekstrak dengan cara direaksikan menggunakan reagen spesifik di dalam tabung reaksi.

a. Uji fenolik

Ekstrak ditambahkan 2 tetes $\mathrm{FeCl}_{3}$, kemudian dikocok. Uji positif fenol bila larutan berwarna kuning kehijauan.

b. Uji flavonoid

Ekstrak ditambahkan 5 tetes etanol, sedikit serbuk Mg, dan 5 tetes $\mathrm{HCl}$ pekat, kemudian dikocok. Uji positif flavonoid bila terbentuk warna kuning.

c. Uji steroid

Ekstrak ditambahkan $2 \mathrm{~mL}$ dietil eter, 10 tetes asam asetat anhidrid, dan 3 tetes $\mathrm{H}_{2} \mathrm{SO}_{4}$ pekat, kemudian dikocok. Uji positif steroid jika larutan berwarna hijau hingga biru.

d. Uji terpenoid

Ekstrak ditambahkan $2 \mathrm{~mL}$ dietil eter, 10 tetes asam asetat anhidrid, dan 3 tetes $\mathrm{H}_{2} \mathrm{SO}_{4}$ pekat, kemudian dikocok. Uji positif terpenoid jika larutan berwarna merah hingga ungu.

e. Uji alkaloid

Ekstrak ditambahkan $10 \mathrm{~mL}$ kloroform serta $0,5 \mathrm{~mL} \mathrm{H}_{2} \mathrm{SO}_{4} 1 \mathrm{M}$, kemudian dikocok. Larutan didiamkan sehingga terbentuk dua lapisan. Lapisan atas dipipet ke dalam tabung reaksi dan ditambahkan 1-2 tetes pereaksi Dragendorff. Uji positif alkaloid bila terbentuk endapan berwarna merah muda.

f. Uji saponin

Ekstrak ditambahkan $2 \mathrm{~mL}$ akuades, kemudian dipanaskan selama 2-3 menit. Larutan dinginkan, kemudian dikocok dengan kuat. Uji positif saponin bila terdapat busa yang stabil selama 30 detik.

g. Uji kandungan total fenolik (TPC)

Kandungan total fenolik ditentukan menggunakan metode Folin-Ciocalteau. Fenol dengan konsentrasi $0-8 \mathrm{mg} / \mathrm{L}$ dibuat sebagai kurva standar dengan dua kali pengukuran. Sebanyak mamasing-masing $0,2 \mathrm{~g}$ ekstrak ditambahkan $0,2 \mathrm{~mL}$ reagen $\mathrm{FC}$, kemudian diaduk selama 15 detik dan didiamkan selama 5 menit. Selanjutnya ditambahkan $2 \mathrm{~mL} \mathrm{Na} \mathrm{CO}_{3} 20 \%$ dan ditepatkan volumenya hingga $5 \mathrm{~mL}$ dengan akuades. Larutan disimpan selama 40 menit, kemudian dianalisis menggunakan spektrofotometer UV-Vis. Absorbansi larutan diamati pada $\lambda 750 \mathrm{~nm}$ dengan dua kali pengukuran. Kandungan total fenolik dinyatakan sebagai ekuivalen fenol dalam $\mathrm{mg} / \mathrm{g}$ ekstrak (Alhabsyi dkk, 2014).

h. Uji kandungan total flavonoid (TFC)

Dibuat kurva kalibrasi kuersitin dengan konsentrasi 2-8 ppm. Sebanyak $20 \mathrm{mg}$ tiap larutan ekstrak ditambahkan $2 \mathrm{~mL} \mathrm{AICl} 32 \%$ kemudian diaduk, selanjutnya dianalisis menggunakan UV-Vis. Absorbansi larutan diamati pada $\lambda 415 \mathrm{~nm}$. Kandungan total flavonoid dinyatakan sebagai ekuivalen kuersitin dalam mg/g ekstrak (Alhabsyi dkk, 2014).

\subsection{Pembuatan larutan DPPH}

Larutan DPPH 40 ppm dibuat dengan menimbang 0,01 g DPPH, selanjutnya dilarutkan dalam labu takar $250 \mathrm{~mL}$ menggunakan metanol hingga tanda batas. Larutan segera digunakan dan dijaga pada temperatur rendah, serta terlindung dari cahaya.

\subsection{Penentuan panjang gelombang maksimum DPPH}

Sebanyak $5 \mathrm{~mL}$ DPPH 40 ppm dianalisis menggunakan UV-Vis pada $\lambda$ 490-534 nm dengan blanko metanol. 


\subsection{Penentuan aktivitas penangkal radikal bebas DPPH (Wulandari dkk., 2013)}

Sebanyak 2 mg setiap ekstrak dibuat menjadi larutan dengan konsentrasi 10, 20, 30, 40, 50, 100, 200, dan 300 ppm. Larutan pembanding (kuersitin) dibuat dengan konsentrasi 2, 4, 6, 8, 10, 20 , 30 , 0 , dan $50 \mathrm{ppm}$. Masing-masing larutan uji sebanyak $1 \mathrm{~mL}$ dimasukkan ke dalam tabung reaksi dan ditambahkan $2 \mathrm{~mL}$ larutan DPPH 40 ppm, kemudian didiamkan pada suhu kamar selama 30 menit. Absorbansi diamati menggunakan spektrofotometer UV-Vis pada $\lambda$ maks $D P P H$ dengan dua kali pengukuran.

\section{HASIL PENELITIAN}

\subsection{Ekstraksi}

Setiap sampel bubur buah pisang dan serbuk kulit pisang jarum diekstrak dengan pelarut metanol $80 \%$, etanol $80 \%$, dan aseton $80 \%$, menggunakan metode refluks selama 2 jam pada suhu pelarut. Hasil ekstraksi berupa ekstrak kental berwarna kuning kecokelatan.

\subsection{Uji Fitokimia}

Hasil uji fitokimia buah dan kulit pisang jarum ditunjukkan pada Tabel 1.

Tabel 1. Uji fotokimia buah dan kulit pisang jarum

\begin{tabular}{|c|c|c|c|}
\hline \multirow[t]{2}{*}{ Senyawa } & \multirow{2}{*}{$\begin{array}{c}\text { Pelarut } \\
(80 \%)\end{array}$} & \multicolumn{2}{|c|}{ Hasil Uji } \\
\hline & & Buah & Kulit \\
\hline \multirow[t]{3}{*}{ Fenolik } & Etanol & + & + \\
\hline & Metanol & + & + \\
\hline & Aseton & + & + \\
\hline \multirow[t]{3}{*}{ Flavonoid } & Etanol & + & + \\
\hline & Metanol & + & + \\
\hline & Aseton & + & + \\
\hline \multirow[t]{3}{*}{ Steroid } & Etanol & - & - \\
\hline & Metanol & - & - \\
\hline & Aseton & - & - \\
\hline \multirow[t]{3}{*}{ Terpenoid } & Etanol & + & + \\
\hline & Metanol & + & + \\
\hline & Aseton & - & + \\
\hline \multirow[t]{3}{*}{ Alkaloid } & Etanol & - & + \\
\hline & Metanol & - & + \\
\hline & Aseton & - & + \\
\hline \multirow[t]{3}{*}{ Saponin } & Etanol & - & + \\
\hline & Metanol & - & + \\
\hline & Aseton & - & + \\
\hline
\end{tabular}

Semua ekstrak buah dan kulit pisang jarum mengandung senyawa antioksidan, yaitu flavonoid dan fenolik. Kedua senyawa ini bersifat polar dan larut pada pelarut polar dan semipolar. Polihidroksi dari flavonoid akan direduksi oleh magnesium dalam asam klorida dalam larutan etanol, sehingga membentuk garam flavilium yang berwarna kuning (Setyowati dkk., 2014).

Adanya senyawa steroid pada sampel ditunjukkan dengan terbentuknya warna hijau hingga biru. Semua ekstrak buah dan kulit pisang jarum tidak mengandung steroid. Hasil uji terpenoid diperoleh warna merah muda pada ekstrak etanol dan metanol, sedangkan ekstrak aseton tidak. Hal ini menunjukkan bahwa senyawa terpenoid pada buah pisang jarum kemungkinan ada dalam jumlah yang sangat kecil, sehingga tidak terekstrak oleh aseton. 
Semua ekstrak kulit pisang jarum menghasilkan warna merah muda pada uji alkaloid, sedangkan ekstrak buah tidak. Ini berarti kulit pisang jarum mengandung senyawa alkaloid, sedangkan buah pisang jarum tidak. Senyawa alkaloid memiliki ciri rasa sepat dan pahit. Buah pisang jarum berasa manis, sehingga tidak mengandung senyawa alkaloid.

Terbentuknya busa yang stabil pada semua ekstrak kulit pisang jarum menandakan adanya senyawa saponin, sedangkan semua ekstrak buah tidak mengandung saponin. Timbulnya busa menunjukkan adanya glikosida yang memiliki kemampuan menghasilkan buih dalam air yang terhidrolisis menjadi glukosa dan senyawa lainnya (Setyowati dkk., 2014).

\subsection{Penentuan kandungan total fenolik (TPC)}

Penentuan TPC merupakan dasar pengujian aktivitas antioksidan. Metode Folin-Ciocalteu digunakan untuk mengukur TPC yang diamati serapannya pada $\lambda 750 \mathrm{~nm}$. Dari data absorbansi larutan standar fenol pada Tabel 2, dibuat kurva standar fenol (Gambar 1).

Tabel 2. Absorbansi larutan standar fenol

\begin{tabular}{ccc}
\hline No & Konsentrasi fenol (ppm) & Absorbansi \\
\hline 1 & 0,00 & 0,000 \\
2 & 1,00 & 0,094 \\
3 & 2,00 & 0,184 \\
4 & 3,00 & 0,273 \\
5 & 4,00 & 0,365 \\
6 & 5,00 & 0,453 \\
7 & 6,00 & 0,543 \\
8 & 7,00 & 0,642 \\
9 & 8,00 & 0,724 \\
\hline
\end{tabular}

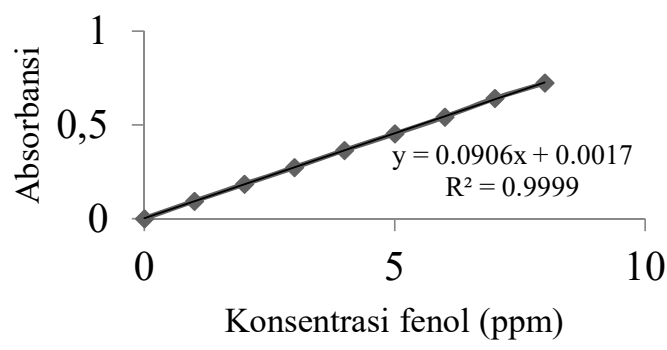

Gambar 1. Kurva standar fenol

Nilai absorbansi yang diperoleh dari masing-masing ekstrak diplotkan terhadap kurva standar fenol, kemudian dihitung TPC seperti pada Tabel 3. 
Tabel 3. Hasil penentuan TPC

\begin{tabular}{llccc}
\hline Sampel & $\begin{array}{c}\text { Pelarut } \\
\text { ( 80\%) }\end{array}$ & Abs & $\begin{array}{c}\text { R } \\
\text { (ppm) }\end{array}$ & $\begin{array}{c}\text { TPC } \\
\text { (mg PE/g } \\
\text { ekstrak) }\end{array}$ \\
\hline Buah & Etanol & 0,091 & 1,00 & 0,0250 \\
& Metanol & 0,115 & 1,28 & 0,0316 \\
\multirow{5}{*}{ Kulit } & Aseton & 0,095 & 1,05 & 0,0257 \\
& Etanol & 0,650 & 7,21 & 0,1757 \\
& Metanol & 0,645 & 7,16 & 0,1756 \\
& Aseton & 0,501 & 5,56 & 0,2679 \\
\hline
\end{tabular}

Kandungan total fenolik tertinggi terdapat pada ekstrak aseton kulit pisang jarum $(0,2679 \mathrm{mg}$ $\mathrm{PE} / \mathrm{g}$ ekstrak), kemudian ekstrak etanol dan metanol. Untuk buah pisang jarum, TPC terbanyak pada ekstrak metanol, selanjutnya ekstrak aseton dan etanol. Hasil menunjukkan bahwa senyawa fenolik dalam buah dan kulit pisang jarum terekstrak dengan baik dalam pelarut aseton, etanol, dan metanol sesuai dengan penelitian Alhabsyi dkk. (2014) dan Kumar dkk. (2014).

\subsection{Penentuan kandungan total flavonoid (TFC)}

Penentuan TFC ekstrak buah dan kulit pisang jarum dilakukan dengan mengamati serapan pada $\lambda 415 \mathrm{~nm}$. Dari data absorbansi larutan standar kuersitin pada Tabel 4, dibuat kurva standar kuersitin (Gambar 4).

Tabel 4. Absorbansi larutan standar kuersitin

\begin{tabular}{ccc}
\hline No & Konsentrasi kuersitin (ppm) & Absorbansi \\
\hline 1 & 2 & 0,117 \\
2 & 4 & 0,234 \\
3 & 6 & 0,347 \\
4 & 8 & 0,473 \\
5 & 10 & 0,571 \\
\hline
\end{tabular}

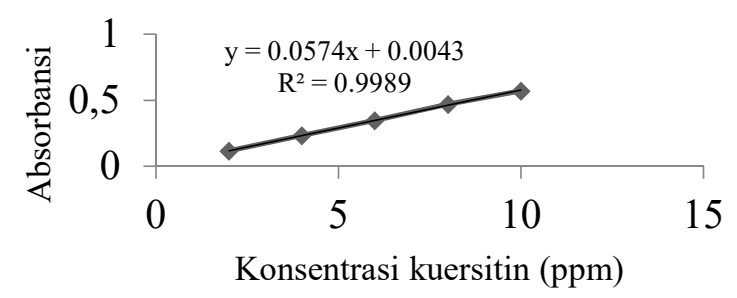

Gambar 2. Kurva standar kuersitin

Nilai absorbansi yang diperoleh dari masing-masing ekstrak diplotkan terhadap kurva standar kuersitin, selanjutnya dihitung TFC seperti pada Tabel 5. 
Tabel 5. Hasil penentuan TFC

\begin{tabular}{llccc}
\hline Sampel & $\begin{array}{c}\text { Pelarut } \\
\text { (80\%) }\end{array}$ & Abs & $\begin{array}{c}\text { R } \\
\text { (ppm) }\end{array}$ & $\begin{array}{c}\text { TFC } \\
\text { (mg QE/g } \\
\text { ekstrak) }\end{array}$ \\
\hline \multirow{2}{*}{ Buah } & Etanol & 0,270 & 4,68 & 1,1615 \\
& Metanol & 0,335 & 5,82 & 1,4466 \\
& Aseton & 0,197 & 3,39 & 0,8412 \\
Kulit & Etanol & 0,218 & 3,75 & 4,5095 \\
& Metanol & 0,237 & 4,27 & 5,1073 \\
& Aseton & 0,156 & 2,67 & 3,2128 \\
\hline
\end{tabular}

Kandungan total flavonoid tertinggi diperoleh dari ekstrak metanol kulit pisang jarum $(5,1073 \mathrm{mg}$ $\mathrm{QE} / \mathrm{g}$ ekstrak), selanjutnya ekstrak etanol dan aseton. Untuk buah pisang jarum, TFC terbanyak pada ekstrak metanol, kemudian ekstrak etanol dan aseton. Hasil menunjukkan bahwa metanol, etanol, dan aseton merupakan pelarut yang baik untuk mengekstrak senyawa flavonoid.

\subsection{Penentuan panjang gelombang maksimum DPPH}

Penentuan $\lambda$ maks DPPH dilakukan dengan mengamati serapan pada $\lambda$ 490-534 $\mathrm{nm}$. Dari hasil pengukuran diperoleh $\lambda$ maks $\mathrm{DPPH}$ adalah $517 \mathrm{~nm}$, yang selanjutnya digunakan dalam penentuan aktivitas antioksidan.

Penentuan aktivitas antioksidan diawali dengan membuat kurva standar untuk menguji linearitas pada sampel. Penentuan aktivitas penangkal radikal bebas DPPH dinyatakan dengan nilai $\mathrm{IC}_{50}$ menggunakan kontrol kuersetin. Pengukuran menggunakan spektrofotometer UV-Vis pada $\lambda 517$ $\mathrm{nm}$, diperoleh nilai absorbansi dari masing-masing konsentrasi. Nilai absorbansi

digunakan untuk perhitungan \% Inhibisi dan $\mathrm{IC}_{50}$ kuersetin. Dari data aktivitas penangkal radikal bebas DPPH kuersetin pada Tabel 6, dibuat kurva standar aktivitas penangkal radikal bebas DPPH kuersetin seperti ditunjukkan pada Gambar 3.

Tabel 6. Aktivitas Penangkal Radikal Bebas DPPH kuersitin

\begin{tabular}{cccc}
\hline No & $\begin{array}{c}\text { C kuersitin } \\
\text { (ppm) }\end{array}$ & $\begin{array}{c}\text { Abs } \\
\text { Rata-rata }\end{array}$ & $\begin{array}{c}\% \\
\text { Inhibisi }\end{array}$ \\
\hline 1 & 2 & 0,714 & 3,19 \\
2 & 4 & 0,663 & 10,10 \\
3 & 6 & 0,602 & 18,38 \\
4 & 8 & 0,520 & 29,49 \\
5 & 10 & 0,459 & 37,76 \\
6 & 20 & 0,291 & 60,54 \\
7 & 30 & 0,177 & 75,92 \\
8 & 40 & 0,088 & 88,07 \\
9 & 50 & 0,012 & 98,38 \\
10 & Kontrol & 0,7375 & \\
\hline
\end{tabular}

Persamaan regresi kurva standar aktivitas penangkal radikal bebas DPPH kuersetin digunakan untuk menentukan nilai $\mathrm{IC}_{50}$ kuersetin. Berdasarkan perhitungan diperoleh nilai $\mathrm{IC}_{50}$ kuersetin 20,48 ppm. 


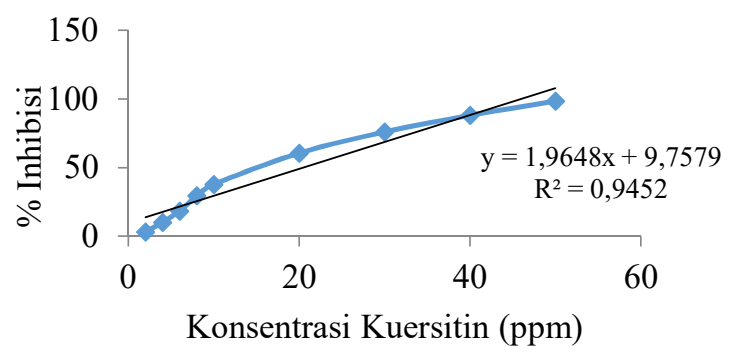

Gambar 3. Kurva standar aktivitas penangkal radikal bebas DPPH kuersitin

Nilai rata-rata absorbansi DPPH+metanol (kontrol) digunakan untuk perhitungan \% inhibisi dan $\mathrm{IC}_{50}$ seperti pada Tabel 7.

Tabel 7. Aktivitas antioksidan ekstrak buah dan kulit pisang jarum

\begin{tabular}{|c|c|c|c|}
\hline Sampel & $\begin{array}{l}\text { Pelarut } \\
(80 \%)\end{array}$ & Persamaan regresi & $\begin{array}{c}\mathrm{IC}_{50} \\
(\mathrm{ppm})\end{array}$ \\
\hline \multirow[t]{3}{*}{ Buah } & Etanol & $\begin{array}{c}y=0.0372 x+9.3432 \\
R^{2}=0.946\end{array}$ & 1092,92 \\
\hline & Metanol & $\begin{array}{c}y=0.0176 x+8.7455 \\
R^{2}=0.916\end{array}$ & 2344,01 \\
\hline & Aseton & $\begin{array}{c}y=0.0112 x+6.6421 \\
R^{2}=0.89\end{array}$ & 3871,24 \\
\hline \multirow[t]{3}{*}{ Kulit } & Etanol & $\begin{array}{c}y=0.104 x+11.95 \\
R^{2}=0.925\end{array}$ & 362,60 \\
\hline & Metanol & $\begin{array}{c}y=0.0737 x+8.8699 \\
R^{2}=0.983\end{array}$ & 558,07 \\
\hline & Aseton & $\begin{array}{c}y=0.1354 x+8.0155 \\
R^{2}=0.972\end{array}$ & 310,08 \\
\hline
\end{tabular}

Ekstrak buah dan kulit pisang jarum menunjukkan peningkatan \% Inhibisi setiap konsentrasinya. Persen inhibisi adalah kemampuan suatu sampel untuk menghambat aktivitas radikal bebas yang berhubungan dengan konsentrasi suatu sampel. Persen inhibisi diperoleh dari perbedaan absorbansi kontrol dan sampel. Penentuan aktivitas antioksidan DPPH menggunakan parameter $\mathrm{IC}_{50}$. Penentuan $\mathrm{IC}_{50}$ dari setiap ekstrak bertujuan untuk menentukan jumlah kandungan ekstrak yang dapat menurunkan intensitas serapan radikal bebas DPPH sebesar 50\% dibandingkan dengan larutan kontrol.

Aktivitas antioksidan yang tinggi pada sampel mengakibatkan perubahan warna larutan DPPH dalam metanol dari ungu menjadi kuning pucat. Hal ini menunjukkan bahwa semua radikal bebas DPPH menjadi berpasangan ketika bereaksi dengan senyawa antioksidan dalam sampel. Senyawa antioksidan mendonorkan atom hidrogen, sehingga warna ungu menjadi memudar. Berdasarkan penelitian, diperoleh ekstrak buah dan kulit pisang jarum tidak menunjukkan perubahan warna yang signifikan sesuai dengan teori. Hal ini terjadi karena kekuatan antioksidan yang dimiliki buah dan kulit pisang jarum sangat lemah. 


\section{KESIMPULAN}

Berdasarkan hasil penelitian, maka dapat disimpulkan:

1. Senyawa antioksidan yang terkandung dalam buah pisang jarum, yaitu fenolik, flavonoid, dan terpenoid, sedangkan kulit pisang jarum, yaitu flavonoid, fenol, terpenoid, alkaloid, dan saponin.

2. Kandungan total fenolik buah pisang jarum, yaitu 0,0250-0,0316 mg PE/g ekstrak, sedangkan kulit pisang jarum 0,1756-0,2679 mg PE/g ekstrak. Kandungan total flavonoid ekstrak etanol, metanol, dan aseton buah pisang jarum adalah 0,8412-1,4466 mg QE /g esktrak, sedangkan kulit pisang jarum adalah 3,2128-5,1073 mg QE/g esktrak.

3. Aktivitas antioksidan $\left(\mathrm{IC}_{50}\right)$ ekstrak etanol, metanol, dan aseton buah pisang jarum adalah 1092,92-3871,24 ppm, sedangkan kulit pisang jarum adalah 310,08-558,07 ppm, sehingga tergolong sebagai antioksidan lemah.

\section{DAFTAR PUSTAKA}

Alhabsyi, D.F., Suryanto, E., dan Wewengkang, D.S,. 2014. Aktivitas Antioksidan dan Tabir Surya pada Ekstrak Kulit Buah Pisang Goroh (Musa acuminate L.) Pharmacon Jurnal IImiah Farmasi, Vol. 3(2):107-114.

Fatemeh, S.R., Saifullah, R., Abbas, F.M.A., dan Azhar, M.E., 2012. Total Phenolics, Flavonoids and Antioxidant Activity of Banana Pulp and Peel flours: influence of variety and stage of ripeness. International Food Research Journal Vol. 19(3):1041-1046.

Jumroon, A., dan Pannipa, Y., 2012. Analysis of Antioxidant Activity at Different Stage in Musa (AA group) 'Kluai Leb Mu Nang'. Agriculture of Technology, King Mongkut's Institute of Technology Ladkrabang Prince of Chumphon Campus, Thailand.

Jun, M.H.Y, Fong, X., Wan, C.S., Yang, C.T., dan Ho, 2003. Comparison of Antioxidant Activities of Isoflavones from Kudzu Root (Puerarua labata, O). Journal Food Science Institute of Technologist, Vol. 68:2117-2112

Kumar, P.R., Srivastavab, S., Singhc, K.K., Mathadc, C., dan Thind, P.S., 2014. Study of Antioxidant and Antimicrobial Properties, Phytochemical Screening and Analysis of Sap Extracted from Banana (Musa acuminata) pseudostem, International Journal of Advanced Biotechnology and Research (IJBR), Vol. 5(4):649-658.

Nagarajaiah, S.B. dan Prakash J., 2011. Chemical Composition and Antioxidant Potential of Peels from Three Varieties of Banana. Asian Journal of Food and Agro-Industry, Vol. 4(1):3146.

Nuramanah, E., Hayat, S., dan Wiwi, S., 2012. Kajian Aktivitas Antioksidan Kulit Pisang Raja Bulu (Musa paradisiacal L. Var. sapientum) dan Produk Olahannya. UPI, Bandung.

Prakash, A., 2001. Medallion Laboratories: Antioxidant Activity. Analytical Progress, Vol. 19(2):1-4.

Saputro, A.H., dan Sudarsono, 2014. Potensi Penangkapan Radikal 2,2-Difenil-1-Pikril Hidrazil (DPPH) oleh Buah Pisang Susu (Musa Paradisiaca L. "Susu") Dan Pisang Ambon (Musa Paradisiaca L. "Ambon"). Traditional Medicine Journal, 19(1), hal. 7-13.

Satuhu, S., dan Supriyadi A., 2005. Budidaya Pengolahaan dan Prospek Pasar Pisang. Penebar Swadaya, Jakarta.

Setyowati, W.A.E., Ariani S.R.D., Ashadi., Bakti M., dan Cici P.R., 2014. Skrining Fitokimia dan Identifikasi Komponen Utama Ekstrak Metanol Kulit Durian (Durio zibethinus Murr). Seminar Nasional Kimia dan Pendidikan Kimia VI, ISBN:979363174-0, hal 271-280.

Uganda National Council for Science and Technology (UNCST), 2007. The Biology of Bananas and Plantains. UNCST Published, Uganda. 
United States Department of Agriculture (USDA), 2009. National Nutrient Database for Standard Reference Release 27 Statistics. The National Agricultural Library, US.

Wulandari, M., Nora, I., dan Gusrizal, 2013. Aktivitas Antioksidan Ekstrak n-Heksana, Etil Asetat dan Metanol Kulit Buah Jeruk Sambal (Citrus microcarpa Bunge). Jurnal Kimia Khatulistiwa, Vol. 2(2), hal. 90-94. 